Dicle Tıp Dergisi / Dicle Med J (2019) 46 (2) : 361 - 368

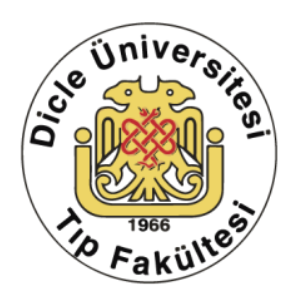

WWW.diclemedj.org

Özgün Araștırma / Original Article

\title{
The releationship between serum levels of gamma glutamyl transferase, mean thrombocyte volume, red blood cell distribution width, neutrophil to lymphocyte ratio with prognose and mortality in patients admitted emergency department with acute ischemic stroke
}

\author{
Nazlı Görmeli Kurt ${ }^{1}$, Cahfer Güloğlu², Yusuf Tamam³ ${ }^{3}$ Mehmet Üstündağ ${ }^{4}$, Murat Orak ${ }^{5}$ \\ 1 Department of Emergency, Ankara City Hospital, Turkey ORCID: 0000-0003-1757-9488 \\ 2 Department of Emergency, University of Dicle Faculty of Medicine, Diyarbakır, Turkey ORCID:0000-0003-1100-3613 \\ 3 Department of Neurology, University of Dicle Faculty of Medicine, Diyarbakır, Turkey ORCID:0000-0002-9886-2017 \\ 4 Department of Emergency, University of Dicle Faculty of Medicine, Diyarbakır, Turkey ORCID:0000-0002-8102-6231 \\ 5 Department of Emergency, University of Dicle Faculty of Medicine, Diyarbakır, Turkey ORCID:0000-0002-0931-3359
}

Received: 20.03.2019; Revised: 14.05.2019; Accepted: 15.05.2019

\begin{abstract}
Objective: In our study, we aimed at determining the levels of Gamma Glutamyl Transferase (GGT), Mean Platelet Volume (MPV), Red Cell Distribution Width (RDW), Neutrophile/Lymphocyte Ratio (NLR), as well as severity of ischemic stroke and prognosis comparison, including the instructive parameters in ischemic stroke treatment, for the patients with ischemic stroke diagnosis.

Methods: This retrospective study was carried put with 473 patients diagnosed with ischemic stroke.40 healthy individuals that meet the requirements with respect to gender and age criteria were included in the study as the control group. The NLR, RDW, MPV, GGT values checked when the cases applied were analyzed with regards to their relation with mortality.

Results: The mean GGT, MPV, RDW, NLR values within the patient group were identified to be significantly high with regards to statistical aspect, compared to the control group. GGT, MPV, RDW, NLR values in all the groups were found to be higher than the control group in line with TOAST and OCSP classifications. Along with the increasing NIHSS and decreasing GKS values, an increase was detected in GGT, MPV, RDW, NLR values. GGT, MPV, RDW and NLR values were significantly higher in the patients who lost their lives compared to the surviving patients, with regards to statistical aspect.

Conclusion: We are of opinion that the prognosis and mortality prediction can be performed in patients with ischemic stroke, thanks to GGT, MPV, RDW, NLR values that are easy to Access and inexpensive blood parameters.
\end{abstract}

Keywords: Blood parameters, Mortality, Stroke.

DOI: $10.5798 /$ dicletip

Yazışma Adresi / Correspondence: Nazlı Görmeli Kurt, Department of Emergency, Ankara City Hospital, Turkey e-mail: nazligormeli@yahoo.com 


\section{Acil Servise Başvuran İskemik İnme Hastalarında Gama Glutamil Transferaz, Ortalama Trombosit Hacmi, Nötrofil Lenfosit Oranı ve Eritrosit Dağılım Genişliği Değerlerinin Prognoz ve Mortalite ile İlişkileri}

\section{Öz}

Amaç: Çalışmamızda Acil servise iskemik inme tanısı ile başvuran hastalarda, Gama Glutamil Transferaz (GGT), Ortalama Trombosit Hacminin (MPV), Eritrosit Dağılım Genişliği (RDW), Nötrofil/Lenfosit Oranı (NLR) düzeyleri ile iskemik inmenin klinik seyir ve prognozu karşılaştırmayı, bunun sonucunda iskemik inmenin tanı ve tedavisinde yol gösterici olabilecek parametrelerin tespitini amaçladık.

Yöntemler: Bu retrospektif çalışma acil servise gelen ve çalışmaya alınma kriterlerine uyan, klinik ve radyolojik olarak iskemik inme tanısı kesinleşen 473 hasta ile yapıldı. Çalışmaya cinsiyet ve yaşça uyumlu 40 sağlıklı birey kontrol grubu olarak dahil edildi. Olguların başvuru anında bakılan NLR, RDW, MPV, GGT değerlerinin mortalite ile ilişkisi incelendi.

Bulgular: Hasta grubunda ortalama GGT, MPV, RDW, NLR değerleri kontrol grubuna göre istatistiksel olarak anlamlı yüksek saptandı. TOAST ve OCSP sinıflamasına göre tüm gruplarda GGT, MPV, RDW, NLR değerleri kontrol grubundan yüksek bulundu. Artan NIHSS ve azalan GKS değerleri ile GGT, MPV, RDW, NLR değerlerinde yükselme tespit edildi. GGT, MPV, RDW ve NLR değerleri ölen hastalarımızda sağ kalan hastalarımıza göre istatistiksel olarak anlamlı derecede yüksekti.

Sonuç: Ulaşılması kolay ve ucuz kan parametleri olan GGT, MPV, RDW, NLR değerleri ile iskemik inme hastalarında prognoz ve mortalite öngörüsü yapılabileceği kanaatindeyiz.

Anahtar kelimeler: Kan parametreleri, Mortalite, İnme.

\section{INTRODUCTION}

Being the third-most cause of death after cardiac diseases and cancer, the stroke is one of the most frequently confronted morbidity and mortality reasons both in Turkey and all over the World ${ }^{1,2}$. One third of alive patients diagnosed with stroke maintain their lives as dependent to other people for their Daily routines. Therefore, apart from being the thirdmost cause of death in the society, the stroke is on the first place of disability in adults ${ }^{3,4}$. Since the mortality and morbidity rates caused by acute stroke are high, it is crucial for these patients to be diagnosed with early mortality prognosis. So we aimed at designate the role of blood parameters for patients with ischemic stroke in mortality and prognosis prediction by using Gamma-glutamyl transferase (GGT), Mean paltelet volume (MPV), Red blood cell distribution width (RDW), Neutrophil/lymphocyte ratio (NLR) values, including Glasgow Coma Score (GCS), National
Institute of Health Stroke (NIHSS), Trial of ORG 10172 in Acute Stroke Treatment (TOAST), Oxfordshire Community Stroke Project (OCSP) scores.

\section{METHOD}

In our study, 473 patients, applying to ER between 01.01.2013 - 30.04.2015, who were diagnosed with ischemic stroke and who met the requirements to be involved in the study were analyzed retrospectively, after obtaining the required approval from the ethics committee. 40 healthy individuals that meet the requirements with respect to gender and age criteria were included in the study as the control group In addition to the demographical data of the patients, RDW, MPV, NLR, GGT values were also noted as applying to ER. ECG findings, application period to hospital, number of seizures, GCS and NIHSS values, including the brain MR reviews were recorded. The patients were split into groups by applying TOAST and OCSP clinical classification with regards to the 
ischemic stroke etiologies. The consciousness of the patients as applying to ER was analyzed with GCS, while the severity and the prognosis were analyzed with NIHSS. Those with GCS score less than 13 were registered as GCS/Severe, while 13-14 values range was recognized as GCS/Moderate, 15 was recognized as GCS/Mild; and those with NICSS score within the range 1-7 were recognized as NIHSS/Mild; while the range between 8-14 was recognized as NIHSS/Moderate, and the NIHSS values equal to 15 and higher were recognized as NIHSS/Severe. The patients with intracerebral haemorrhage, acute or chronical haemorrhage, cancer, liver diseases, history of alcohol use, including the cases with no data available were removed from the study.

Univariety statistical analysis were done by using chi-square test for categorical variables and student-t test for permanent variables. Numerical variables were given as mean \pm SD. $\mathrm{P}<0.05$ were accepted statistically significant

\section{RESULTS}

In our study, 236 of the 473 patients (49.9\%) were male, while 237 of them (50.1\%) were female. The age average of the patients were calculated as 62,61+15,93 years. $19(47.5 \%)$ of the cases comprising the control group were male, while 21 (52.5\%) of them were female; and the age average in the control group was $63,48+14,47$ years. No statistical significant difference was detected with regards to gender and age between the control group and patient group ( $p$ values, respectively: $p=0.87, p=0.739$ ).

We detected the mean application time to hospital of the patients as 6,53+9,28 hours.

The mean hospitalization period of 473 patients with stroke was calculated to be $15+27.35$ days in our study.

The patients were classified as follows, as per their GCS Scores while applying to ER: 44 (9.3\%) patients in GCS/Severe group, 54
(11.4\%) patients in GCS/moderate group, 375 (79.3\%) patients in GCS/mild group.

The mean NIHSS score of the patients was calculated to be 7,82. There were 323 (68.3\%) patients in NIHSS/mild group, while 84 $(17.8 \%)$ of them were in NIHSS/moderate group, and $66(14 \%)$ of them were in NIHSS/severe group.

The stroke sub-types are classified as follows as per TOAST classification: 316 (66.8\%) of the patients were in atherosclerotic infarct group, while $23(4.9 \%)$ of them were in cardioembolic group, $59(12.5 \%)$ of them were in small vessel occlusion, and 75 (15.8\%) of them were in other causes group.

As per the OCSP classification 64 (13.5\%) of the patients were in total anterior circulation infarcts (TACI) group, while 167 (35.5\%) were in partial anterior circulation infarcts (PACI) group, 158 (33.4\%) were in lacunar infarcts (LACI) group and 84 (17.8\%) were in posterior circulation infarcts (POCI) group.

The mean GGT, MPV, RDW, NLR values within the patient group were detected to be significantly high with regards to statistical aspect, compared to the control group $(\mathrm{p}<0,001)$ (Table 1).

We did not detect a significant difference between the male and female gender in stroke cases concerning the GGT $(p=0,102)$, MPV $(p=0,190), \operatorname{RDW}(p=0.253)$, NLR $(p=0,932)$ values.

Table 1: Mean GGT, MPV, RDW, NLR values of control \& patient groups.

\begin{tabular}{|c|c|c|c|}
\hline & $\begin{array}{c}\text { Control groups } \\
\text { (mean+SD) }\end{array}$ & $\begin{array}{c}\text { Patient } \\
\text { groups } \\
\text { (mean+SD) }\end{array}$ & $\mathrm{P}$ \\
\hline $\begin{array}{c}\text { GGT } \\
(\mathrm{U} / \mathrm{L} ; \mathrm{mean}+\mathrm{SD})\end{array}$ & $13,78+5,20$ & $32,92 \pm 28,62$ & $<0,001$ \\
\hline $\begin{array}{c}\text { MPV } \\
(\mathrm{fL} ; \text { mean+SD) }\end{array}$ & $6,86+1,17$ & $9,63+4,44$ & $<0,001$ \\
\hline $\begin{array}{c}\text { RDW } \\
(\% ; \text { mean+SD) }\end{array}$ & $12,48+1,05$ & $16,24+4,42$ & $<0,001$ \\
\hline $\begin{array}{c}\text { NLR } \\
(\text { mean+SD) }\end{array}$ & $2,17+0,72$ & $4,57+4,07$ & $<0,001$ \\
\hline
\end{tabular}


The patients were split into 4 groups based on TOAST and OCSP classifications; 5 groups, including the control group, were compared in terms of GGT, MPV, RDW, NLR values, and the values in all the patient groups were higher than those in the control group (Table 2), (Table 3).

When the patients were compared with regards to their GGT, MPV, RDW, NLR values as per Glasgow Coma Scale (GCS) while applying to ER, GGT $(p=0,001)$, RDW $(p=<0,001)$ and NLR $(p=0,002)$ values were significantly higher in GCS/Severe group than the other groups (Table 4).

Comparing the patients with regards to their GGT, MPV, RDW, NLR values as per their NIHS scores as applying to ER, GGT ( $\mathrm{p}=0,001)$, RDW $(p=<0,001)$ and NLR $(p=0,001)$ values were found to be significantly higher in NIHSS/severe (15 and higher) group than the other groups (Table 5).

$58(12.3 \%)$ of 473 patients, included in the study, lost their lives; 31 (53.4\%) of these patients were female, while $27(46.6 \%)$ of them were male. The age average of the patients that lost their lives was $74,47+11,21$ years, while the age average of those surviving was calculated to be $61,00+15,70$ years. We detected a statistically significant differences with regards to the age average between the patients group that lost their lives and that survive $(p<0,001)$. Additionally, we also found that the mortality ratio in female patients was higher compared to mortality ratio in male patients $(\mathrm{p}<0,001)$.

Table 2: The relation between blood parameters and TOAST groups.

\begin{tabular}{|c|c|c|c|c|c|c|}
\hline & Control group & Atherosclerotic & Cardioembolic & $\begin{array}{c}\text { Small Vessel } \\
\text { Occlusion }\end{array}$ & Other Causes & P \\
\hline $\begin{array}{c}\text { GGT } \\
(\mathrm{U} / \mathrm{L} ; \mathrm{mean}+\mathrm{SD})\end{array}$ & $13,78 \pm 5,20$ & $33,11 \pm 28,05$ & $68,45 \pm 27,86$ & $29,35 \pm 27,40$ & $24,82 \pm 24,64$ & $<0,001$ \\
\hline $\begin{array}{c}\text { MPV } \\
(\mathrm{fL} ; \text { mean+SD) }\end{array}$ & $6,86 \pm 1,75$ & $7,83 \pm 1,78$ & $7,52 \pm 1,82$ & $12,31 \pm 5,49$ & $15,48 \pm 5,48$ & $<0,001$ \\
\hline $\begin{array}{c}\text { RDW } \\
(\% ; \text { mean+SD) }\end{array}$ & $12,48 \pm 1,05$ & $14,29 \pm 3,59$ & $16,85 \pm 4,82$ & $21,86 \pm 2,40$ & $20,43 \pm 2,65$ & $<0,001$ \\
\hline $\begin{array}{c}\text { NLR } \\
(\mathrm{mean}+\mathrm{SD})\end{array}$ & $2,17 \pm 0,72$ & $4,50 \pm 3,79$ & $11,08 \pm 6,41$ & $3,90 \pm 3,41$ & $3,54 \pm 3,14$ & $<0,001$ \\
\hline
\end{tabular}

$50(86.2 \%)$ of 180 patients with AF (Atrial Fibrillation) in their Electrocardiography (ECG) lost their lives. We detected a statistically significant relation between $\mathrm{AF}$ presence in ECG and mortality $(\mathrm{p}<0,001)$.

$17.2 \%$ of the patients who lost their lives applied to ER on their first attack, however the number of attacks in $82.8 \%$ of the patients was higher than one. A statistically significant relation was found between the number of attacks that is more than one and mortality $(\mathrm{p}<0,001)$.

A significant relation was detected between the atherosclerotic infarct presence and mortality as per TOAST classification $(p<0,001)$. No statistically significant relation was detected between cardioembolic infarct and mortality $(p=0,183)$. A statistically significant relation was found between small vessel occlusion \& other causes presence and survival $(\mathrm{p}<0,001)$.

In the study, a significantly significant relation was detected between TACI presence and mortality $(p<0,001)$. Additionally, a statistically significant relation was found between LACI, PACI, POCI presence and survival ( $\mathrm{p}$ values, respectively: $\mathrm{p}<0,001 \mathrm{p}<0,001 \mathrm{p}=0,005$ ).

We found that GGT, MPV, RDW and NLR values were significantly higher in the patients who lost their lives compared to those survived, with respect to statistical aspect ( $p$ values, respectively: $p<0,001, \quad p=0,002, \quad p<0,001$, $\mathrm{p}=0,002$ ) (Table 6). 
Table 3: The relation between the blood parameters and OCSP \& Control group.

\begin{tabular}{|c|c|c|c|c|c|c|}
\hline & Control group & LACI & TACI & PACI & POCI & P \\
\hline $\begin{array}{c}\text { GGT } \\
(\mathrm{U} / \mathrm{L} ; \text { mean+SD) }\end{array}$ & $13,78 \pm 5,20$ & $28,98 \pm 25,39$ & $42,33 \pm 37,81$ & $31,56 \pm 26,19$ & $36,22 \pm 29,76$ & $<0,001$ \\
\hline $\begin{array}{c}\text { MPV } \\
(\mathrm{fL} ; \text { mean+SD) }\end{array}$ & $6,86 \pm 1,75$ & $13,01 \pm 5,82$ & $7,76 \pm 1,47$ & $8,05 \pm 2,13$ & $7,66 \pm 1,56$ & $<0,001$ \\
\hline $\begin{array}{c}\text { RDW } \\
(\% ; \text { mean+SD })\end{array}$ & $12,48 \pm 1,05$ & $20,69 \pm 2,43$ & $19,93 \pm 2,62$ & $12,52 \pm 1,27$ & $12,26 \pm 1,08$ & $<0,001$ \\
\hline $\begin{array}{c}\text { NLR } \\
(m e a n+S D)\end{array}$ & $2,17 \pm 0,72$ & $4,26 \pm 3,79$ & $6,53 \pm 5,83$ & $4,12 \pm 3,29$ & $4,60 \pm 4,07$ & $<0,001$ \\
\hline
\end{tabular}

Table 4: The relation between the blood parameters and Glasgow Coma Scale (GCS).

\begin{tabular}{|c|c|c|c|c|}
\hline & GCS/Severe (<13) & GCS/Moderate (13-14) & GCS/Mild (15) & P \\
\hline $\begin{array}{c}\text { GGT } \\
(\mathrm{U} / \mathrm{L} ; \text { mean+SD) }\end{array}$ & $* 47,72+44,41$ & $33,28+25,84+25,98$ & 0,001 \\
\hline $\begin{array}{c}\text { MPV } \\
\text { (fL; mean+SD) }\end{array}$ & $8,06+1,42$ & $8,16+2,78$ & $* 10,03+4,78$ & 0,001 \\
\hline $\begin{array}{c}\text { RDW } \\
(\% ; \text { mean+SD) }\end{array}$ & $* 19,09+3,38$ & $16,68+4,09$ & $15,83+4,45$ & $<0,001$ \\
\hline $\begin{array}{c}\text { NLR } \\
(\text { mean+SD })\end{array}$ & $* 6,56+5,51$ & $4,73+4,69$ & $4,30+3,70$ & 0,002 \\
\hline
\end{tabular}

Table 5: The relation between the blood parameters and NIHS scale.

\begin{tabular}{|c|c|c|c|c|}
\hline & $\begin{array}{c}\text { NIHSS / Mild } \\
(1-7)\end{array}$ & $\begin{array}{c}\text { NIHSS / Moderate } \\
(8-14)\end{array}$ & $\begin{array}{c}\text { NIHSS/Severe } \\
(>15)\end{array}$ & P \\
\hline $\begin{array}{c}\text { GGT } \\
(\mathrm{U} / \mathrm{L} ; \text { mean+SD) }\end{array}$ & $30,87+26,53$ & $31,35+23,21$ & $* 44,97+40,03$ & 0,001 \\
\hline $\begin{array}{c}\text { MPV } \\
(\mathrm{fL} ; \text { mean+SD) }\end{array}$ & $* 10,13+4,91$ & $8,96+3,71$ & $8,02+1,36$ & $<, 001$ \\
\hline $\begin{array}{c}\text { RDW } \\
(\% ; \text { mean+SD) }\end{array}$ & $15,97+4,52$ & $15,13+3,95$ & $* 19,00+3,31$ & $<0,001$ \\
\hline $\begin{array}{c}\text { NLR } \\
(\text { mean+SD) }\end{array}$ & $4,36+3,80$ & $4,07+4,07$ & $* 6,25+4,94$ & 0,001 \\
\hline
\end{tabular}

Table 6: The relation between the blood parameters and the mortality.

\begin{tabular}{|c|c|c|c|}
\hline & $\begin{array}{c}\text { Dead } \\
(\text { mean+SD })\end{array}$ & $\begin{array}{c}\text { Alive } \\
(\text { mean+SD })\end{array}$ & $\mathrm{P}$ \\
\hline $\begin{array}{c}\text { GGT } \\
(\mathrm{U} / \mathrm{L} ; \text { mean+SD) }\end{array}$ & $47,21+41,54$ & $30,93+25,76$ & $<0,001$ \\
\hline $\begin{array}{c}\text { MPV } \\
(\mathrm{fL} ; \text { mean+SD) }\end{array}$ & $9,87+4,66$ & $7,95+1,40$ & 0,002 \\
\hline $\begin{array}{c}\text { RDW } \\
(\% ; \text { mean+SD) }\end{array}$ & $19,27+3,15$ & $15,82+4,41$ & $<0,001$ \\
\hline $\begin{array}{c}\text { NLR } \\
(\text { mean+SD })\end{array}$ & $6,14+5,01$ & $4,35+3,88$ & 0,002 \\
\hline
\end{tabular}

\section{DISCUSSION}

In our study, we found that the GGT values was significantly high in the patient group, compared to the control group, as similar to other studies 5,6 . On the studies carried out by Akinci, et al., aimed at analyzing the stroke patients, they found the GGT values in cardioembolic group significantly higher in small vessel occlusion and atherosclerotic group as per TOAST classification 6 .

Similarly, we found that the GGT values in cardioembolic group were significantly higher 
than atherosclerotic, small vessel occlusion and other groups in our study. This makes us consider the increase the effected vein diameter, including a relative increase in GGT values. The relation between OCSP groups and GGT was analyzed in the study carried out by Gurbuzer et all. ${ }^{5}$. In our study, we detected a significant rise in all the OCSP sub-groups compared to the control group, with respect to the GGT values. Comparing the groups within themselves, we found that GGT values were significantly higher in TACI, PACI and POCI groups compared to the control group. We think that the GGT values of ischemic SVO patients checked when they apply to the hospital provide us with valuable information concerning the infarct area.

Akinci, et all. did not detect any significant relation between NIHS score and GGT in their studies 6 . As a different finding in our study, we detected an increase in GCS and GGT values decreasing with the increase in NIHSS. We think that this can be useful for poor prognosis for the patients. In the previous studies, significant relation had been found between GGT and mortality with regards to cardiovascular diseases, coronary artery disease, diabetes mellitus and stroke ${ }^{6-8}$. In our study, in accordance with the previous studies, we detected GGT values with significant increase in the patients who lost their lives, compared to those survived. In the recent studies, including out study, the GGT values have been found to be high in patients suffering from stroke. We think that the serum GGT enzyme is related to atherosclerosis, and that there is an increase in GGT value as a result of oxidative stress developing in cerebral ischemia.

In addition to the studies carried out on patients suffering from stroke, which found the MPV values in the patient group to be significantly higher than the control group there are also studies that found no significant difference between these two groups ${ }^{9-11}$. In our study, we found that the MPV value in ischemic stroke patients was significantly higher compared to the control group.

Similarly, in other studies, the coronary syndrome, diabetes mellitus, cerebrovascular cases, pre-eclampsia, renal artery stenosis, hypercholesterolemia, smoking and sepsis were found to have an impact on the increase of MPV12. Additionally, there are also studies, in which a significant relation has been detected between MPV and mortality ${ }^{10,13}$. In our study, we found a significant relation between MPV value and mortality in the ischemic stroke patients. We think that this is caused by the large platelets being defined as stress platelets, and increased MPV being related to increased growing of megakaryocytes as a respond to thrombopoietic stress ${ }^{14}$.

In our study, as similar to the previous studies, we detected that the RDW value is significantly higher in patient groups, compared to the control group ${ }^{15,16}$. The RDW values in our study were detected to be high in GCS/Severe groups, as similar to the study carried out by Kara et al., and we detected an increase in the RDW value with increasing NIHSS ${ }^{15}$. We think that it can be more efficient in terms of time and loss of strength to analyze RDW values that are easyto-access, instead of NIHS score, which, apart from being harder to access, took longer as analyzing the prognosis and mortality. Martinez-Velilla, et all. found that RDW is related to all-cause mortality ${ }^{17}$. Ani, et al showed that RDW was higher in the patients who lost their lives, compared to those survived, and that RDW values were related to mortality for patients suffering from stroke ${ }^{18}$. In our study, as similar to the previous studies, the RDW values were found to be significantly higher in patients who lost their lives after stroke, compared to those who survived.

We think that the severity of the mechanisms recognized to be increasing the RDW by affecting the bone marrow like increased oxidative stress, inflammation, ischemia is 
caused by the impact on the mortality of these patients.

We found the NLR value to be significantly higher in the patient group, compared to the control in our study, as similar to the previous studies $^{19,20}$. In the recent years, NLR; as an index reflecting not only the acute state in inflammation with regards to neutrophile level, and also the lymphopenia developing after acute physiological stress, has come into use ${ }^{21}$. Based on the data we obtained, we think that the cerebral ischemia secondary stress increases the NLR value. In the study carried out by Gökhan et all., a significant relation was found between the early stage mortality and NLR value ${ }^{22}$. Tokgoz et al. came to the same conclusion, as well ${ }^{19}$. In our study, as similar to the previous studies, NLR values were found to be significantly higher in the patients who lost their lives.

We also detected an increase the NLR value with increasing GCS values and decreasing NIHSS values, in our study. We think that the NLR values of the patients suffering from stroke, checked when they apply to the hospital, may provide us with valuable information concerning the severity of the stroke.

\section{CONCLUSION}

As a conclusion, we are of opinion that the prognosis and mortality prediction can be performed in patients with ischemic stroke that is placed near the top causes of mortality and morbidity in all over the world, thanks to GGT, MPV, RDW, NLR values that are easy to access and inexpensive blood parameters.

Our study was presented as an Oral Presentation at the 9th Asian Conference on Emergency Medicine \& 13th Turkish Emergency Medicine Congress, 2017.
Conflicts of interest: The authors have no conflict of interests to declare.

Financial Disclosure: The authors declared that this study has received no financial support.

\section{REFERENCES}

1. Lopez AD, Mathers CD, Ezzati M, Jamison DT, Murray CJ. Global and regional burden of disease and risk factors, 2001: systematic analysis of population health data. Lancet.2006; 367: 1747-57.

2. Onat A, Hergenc G, Can G. Prospective validation in identical Turkish cohort of two metabolic syndrome definitions for predicting cardiometabolic risk and selection of most appropriate definition. Anatol J Kardiol.2007; 7: 29-34.

3. Malmgren R, Warlow C, Bamford J, Sandercock P. Geographical and secular trends in stroke incidence. Lancet, 1987; 2: 1196-201.

4. Warlow CP. Epidemiology of stroke. Lancet, 1998; 352: 1-4.

5. Gürbüzer N, Gözke E. Gamma Glutamyl Transferaz Levels in Patients with Acute ischemic Stroke Hindavi Publishing Corparation Volume 2014 article ID: 170626.

6. Akıncı E, Doğan N.Ö. Can we use serum gamma glutamiyl transferase levels to predict early mortality in stroke? Pak J Med Sci. 2014 May-Jun; 30: 606-10. doi: $10.12669 /$ pjms.303.4456

7. Rutmann E, Brant L, Concin H, Gamma Glutamyl Transferase as a risc factor for cardiyovascüler disease Mortality Circulation 2005; 112: 2130-7.

8. J. B. Whitfield, "Gamma glutamyl transferase," Critical Reviewsin Clinical Laboratory Sciences, vol. 38, no. 4, pp. 263-355, 2001.

9. Durdu T, Yllmaz F, Aslan ED, The value of mean platelet volüme in ischemic stroke patient (JPMA 63: 1468; 2013).

10. Arikanoglu A, Yucel Y, Acar A, et all. The relationship of the mean platelet volume and C-reactive protein levels with mortality in ischemic stroke patients. Eur Rev Med Pharmacol Sci. 2013; 17: 1774-7.

11. Tamer D, Fevzi Y, Deniz AE, et all. The value of serum mean platelet volume in ischaemic stroke patient. JPMA. 2013; 63 : 1509- 10.

12. Ford HC, Toomath RJ, Carter JM, Delahunt JW, Fagerstrom JN. Mean platelet volume is increased in hyperthyroidism. Am J Hematol. 1988; 27: 190- 3.

13. Arevalo-Lorido JC, Carretero-Gomez J, Alvarez-Oliva $\mathrm{A}$, et all. Mean platelet volume in acute phase of ischemic stroke, as predictor of mortality and 
functional outcome after 1 year. J Stroke Cerebrovasc Dis.2013; 22: 297-303.

14. Martin JF, Bath PM, Burr ML. Influence of platelet size on outcome after myocardial infarction. Lancet.1991; 338: $1409-11$.

15. Kara H, Degirmenci S, Bayir A, et all. Red cell distribution width and neurological scoring systems in acute stroke patients. Neuropsychiatr Dis Treat. 2015; 11: 733-9.

16. Ramirez-Moreno JM, Gonzalez-Gomez M, Ollero-Ortiz A, et all. Relation between red blood cell distribution width and ischemic stroke: a case-control study. Int J Stroke. 2013; 8: E36.

17. Martinez-Velilla N, Ibanez B, Cambra K, AlonsoRenedo J. Red blood cell distribution width, multimorbidity, and the risk of death in hospitalized older patients. Age.2012; 34: 717-23.

18. Ani C, Ovbiagele B. Elevated red blood cell distribution width predicts mortality in persons with known stroke. J Neurol Sci.2009; 277: 103-8.
19. Tokgoz S, Keskin S, Kayrak M, Seyithanoglu A, Ogmegul A. Is neutrophil/lymphocyte ratio predict to short-term mortality in acute cerebral infarct independently from infarct volume? J Stroke Cerebrovasc. 2014; 23: 2163-8.

20. Buck BH, Liebeskind DS, Saver JL, et all. Early neutrophilia is associated with volume of ischemic tissue in acute stroke. Stroke. 2008; 39: 355-60.

21. Gibson PH, Cuthbertson BH, Croal BL, et all. Usefulness of neutrophil/lymphocyte ratio as predictor of new-onset atrial fibrillation after coronary artery bypass grafting. Am J Cardiol. 2010; 105: 186-91.

22. Gokhan S, Ozhasenekler A, Mansur Durgun H, et all. Neutrophil lymphocyte ratios in stroke subtypes and transient ischemic attack. Eur Rev Med Pharmacol Sci. 2013; 17: 653-7. 